University of Nebraska - Lincoln

DigitalCommons@University of Nebraska-Lincoln

H. W. Manter Laboratory Library Materials

$9-1923$

\title{
A Founder of American Parasitology, Joseph Leidy
}

Henry Baldwin Ward

University of Illinois

Follow this and additional works at: https://digitalcommons.unl.edu/manterlibrary

Part of the Parasitology Commons

Ward, Henry Baldwin, "A Founder of American Parasitology, Joseph Leidy" (1923). H. W. Manter Laboratory Library Materials. 19.

https://digitalcommons.unl.edu/manterlibrary/19

This Article is brought to you for free and open access by DigitalCommons@University of Nebraska - Lincoln. It has been accepted for inclusion in H. W. Manter Laboratory Library Materials by an authorized administrator of DigitalCommons@University of Nebraska - Lincoln. 


\section{The Journal of Parasitology}

\begin{tabular}{cccr}
\hline \hline Volume 10 & SEPTEMBER, 1923 & Number \\
\hline \hline & & & \\
THE & FOUNDER & OF AMERICAN PARASITOLOGY, \\
& & JOSEPH LEIDY
\end{tabular}

Most fields of biology are opened up gradually, at least to the extent that pioneer workers patiently accumulate data, usually in the form of disassociated and unrelated observations and isolated details, before the time is ripe for the master mind which builds of this inchoate material a new part of the great structure of science. The field of parasitology in America constitutes a striking exception to this general principle. Prior to 1846 no one in this country appears to have devoted any attention to the subject and the few casual notes on parasites which have been dug out of earlier writings on other topics are too scanty and superficial to furnish foundation material for any study. Accordingly when in that year a young Philadelphia physician, scarce 23 years of age, began to devote his attention to studies on parasitic worms, he found himself confronted with the double task of gathering the material and of organizing it into scientific form. Moreover, while in some other fields in which he published other investigators added interest and zest by their contributions, here he worked alone and it was more than a quarter of a century before any other student in this country contributed in other than casual fashion to the subject of parasitology. Yet the work he undertook was performed so thoroughly that the descriptions and interpretations he published within the decade from 1846 to 1856, sufficed not only to lay the foundations of American parasitology, but also yielded him recognition as an authority in that field everywhere and contributed materially to the advancement of the subject in Europe where it had been studied intensively for more than half a century.

Joseph Leidy was born in Philadelphia on Sept. 9, 1823. Nature had endowed him admirably for the part he was to play. Sprung from a lineage that represented the best in two great nations of the old world, he inherited artistic skill of no common order, love of nature and life, keeness of perception, accuracy of judgment and that foresight truly characteristic of a master mind, which enabled him to predict successfully the decisions of the future. These conditions will stand out more clearly after a review of the general history of the family and the special training of the man. 
THE LEIDY FAMILY

Following close after the pilgrimage of William Penn into the Rhenish Palatinate came to this country a wave of migrants from Germany that began about 1688 and contributed an important early element to the American stock. Among those who came were the first American ancestors of Joseph Leidy. In the old world the name was spelled variously, Leydig, Lydig and Leidig, and was anglicized later by the English authorities in Pennsylvania into Leidy.

As early as 1338 one of this name, Johan Leydig, was living at Wilsnach in Swabia. Among his descendants was a chief burgher of Wilsnach, Joachim Leydig, whose son, the Rev. Matthew Leydig, studied theology with Luther at Wittenberg and was ordained by him in 1550. In 1552 he was called to the German Reformed Church at Halle where he died in 1601 . He published a translation of the Bible (Berlin, 1586) and later the Lutheran vespers and psalms of David. Another of the family, Joachim Leydig, also a native of Halle, served as pastor of the Reformed Church at Königsberg in Prussia, until in 1571 as the result of a doctrinal controversy he returned to Halle. Jacob Leydig, grandson of the Rev. Johan Leydig, and a scholar of note, published in 1677 a history of the ancient electors of Prussia. It was in this, the XVII Century, that armorial bearings were granted to the head of the house, Joachim Leydig, in recognition of his public services in founding a hospital. It is interesting to note that this same family has produced in recent years one other highly distinguished biologist, Professor Franz Leydig of Würzburg and Bonn whose great grandfather was a brother of Joseph Leidy's great grandfather.

Following the Thirty Years' War, the Palatinate was subjected to religious persecutions and as a direct result of these John Jacob Leydig emigrated from Wittenberg. He arrived in Philadelphia in 1729 and settled on a tract of 400 acres purchased from the Penns. This early settler, great grandfather of the naturalist, established a settlement known even to the present day as Leidytown, although the postoffice bearing this name is all that remains of the original town. His son, John Jacob Leidy, who fell heir to the homestead, found upon his land deposits valuable in the manufacture of pottery and utilized them so successfully that specimens of his workmanship of evident artistic merit are preserved in the exhibit of pottery of Colonial times at Memorial Hall, Philadelphia. During the American Revolution he served as an officer in the Pennsylvania forces and played an active part in the events of the war in that region. His wife, Joseph Leidy's paternal grandmother, was Marie LeFebre, a sister of Francis Joseph LeFebre a marshal of Napoleon I and a peer of France. To this joint FrenchGerman ancestry the grandson clearly owed many of the traits which enabled him to win such a conspicuous success. 
His son, Philip Leidy, inherited his father's land, and at the close of the Revolution settled in the city of Philadelphia where he engaged in industrial pursuits with marked financial success. During the war of 1812 he served as an officer. After Marshal LeFebre's death, being deeply involved in military affairs, he named his sons Francis and Joseph, and hoped they would both seek fame in military careers. While the one son, Joseph, with whom this article is directly concerned, served with distinction in the Civil War, it was as surgeon in a military hospital and not in a position such as his father evidently had in mind.

Joseph Leidy's mother was Catherine Mellick (Moelich) who also was descended from natives of the Rhineland that had come originally to New Jersey and had later moved to Pennsylvania. She died when Joseph, who was her third child, was only twenty months old and he was reared by a stepmother, Christiana Mellick, of whose careful training Leidy often made grateful acknowledgement: "The only mother I have known," he said at one time, "she was all in all to me, the one to whom I owe all that I am."

\section{THE STORY OF LEIDY'S LIFE}

During his early education the boy manifested little ability in the classical studies which were standard in that day but showed an eager interest in natural history even though it was not included in the curriculum. In his wanderings into the country in search of minerals, flowers and insects he absented himself at times from school and was indifferent to those sports which tempted most boys. His leisure seems to have been devoted to drawing objects of natural history and a note book still extant and dated 1833 shows that even at the age of ten he had cultivated, alone by himself, that accuracy in observation and fidelity in delineation which gave its high value to his later work. His father was so deeply impressed by this phase of his work that he resolved to make an artist of the boy. His mother, who was a woman of marked intelligence and foresight, had a firm conviction that her sons should receive a professional education and as Leidy later stated, her strength "carried the point." His skill in making minute dissections already displayed on various occasions and his mother's confidence that she saw in him the traits which would make a great physician, led first to the study of anatomy under a private teacher and later to his matriculation at the University of Pennsylvania, where he received the degree of doctor of medicine in 1844. But professional duties proved irksome and were entirely abandoned two years later in favor of scientific pursuits.

The story of Leidy's active life and his relations to the Philadelphia Academy of Natural Sciences, with which his name is inseparably connected and to whose upbuilding and reputation he made most note- 
worthy contributions in every department, has been so fully portrayed by contemporary biographers that the subject may be passed over here with a brief reference to the sources of information. Many biographical sketches of Leidy have been published. Among those of general scope that of Chapman (1891) which was read before the Philadelphia Academy soon after Leidy's death is rich in personal material and broad in its treatment of the career of the great naturalist. Some later sketches are marred by the introduction of unverified personal episodes. The most recent biography, prepared by H. F. Osborn for the National Academy of Sciences, paints a vivid and most satisfactory picture of Leidy "as the founder of vertebrate paleontology in America and as the last great naturalist of the old type." Osborn lists a dozen other biographical sketches, most of which handle Leidy's career from the viewpoint of a worker in some particular field without attempting to cover critically all the activities of this many sided man. Only one of these sketches, and that a brief one (Ward, 1900), essays to treat particularly Leidy's contributions in the field of parasitology. In 1917 Pfender published a valuable paper on the important contributions to medicine made by Leidy." 1

An examination of the studies which have been made on Leidy's life and work justifies the criticism that in the main adequate consideration has not been given to the leading part he played in laying foundations and developing the field of parasitology, helminthology and medical zoology. This may be due in part to a failure of his biographers to recognize this as a distinct field of work and yet even this factor is not sufficient to explain the absence of appropriate emphasis on his extensive and valuable contributions to knowledge in this field. His earliest biographer, Chapman, who wrote very fully of Leidy's other work, offers little comment on the contributions made to parasitology. A short discussion of the work on Trichina and a single paragraph on the investigations on Gregarine structure, or less than a page in all, is devoted to recording studies of fundamental importance. And H. F. Osborn, whose biographic sketch of Leidy merits high praise, speaks of his "two chief lines of investigation, the Protozoa and fossil vertebrates." To be sure Osborn discusses under the heading of contributions to microscopy the studies in helminthology which deservedly brought to Leidy a world-wide reputation and later quotes from those studies and from the views of recent investigators to demonstrate the value of Leidy's work in parasitology.

But even with that the record does scant justice to Leidy's pioneer work in this field. The reason may perhaps lie in the fact that the

1. It is to be regretted that the admirable sketch by Dr. F. H. Garrison, of which I have just seen a copy, is printed where it must remain generally inaccessible. 
development of the subject in America has even yet hardly reached the stage where a just estimate of Leidy's contributions to it can fairly be made. One writer quoted by Osborn speaks half apologetically of Leidy's work "from the point of view of a specialist of 1910." I cannot feel that such an attitude is justifiable and find much to indicate that Leidy was so far in advance of his generation in the field of parasitology, that only within recent years have students in this field come to the point of understanding his descriptions and beginning to see for themselves the things he described a generation back. No doubt these descriptions are often unfortunately brief and require restatement on the basis of repeated study to bring them fully into line with present day practices but they have in general come out well from such critical examination and the work gains in strength with such restudy. Abroad his work in this field was highly acclaimed both on the continent and in England. In an address in 1891 the president of the Linnaean Society of London refers to him as the most distinguished biologist of his time in America and adds that he contributed researches in helminthology and parasitology "of epoch-making importance." An extended biography of Leidy is in the course of preparation by his nephew, Dr. Joseph Leidy II of Philadelphia, and to him the author of this sketch is deeply indebted for data and suggestions as well as for a general revision of this manuscript to insure its correctness.

\section{LEIDY'S PERSONALITY AND INTELLECTUAL POWER}

All of Leidy's associates unite in ascribing to him a personality of a most engaging type so that when on April 30, 1891, he passed away at the close of a long and active life, he left not a single enemy but a multiude of friends. His interest and devotion to his scientific pursuits was marked by all and his enthusiasm as well as his power in presenting his observations, made him a welcome speaker at scientific gatherings and a most successful teacher in his college work. For many years he visited the public market on Wednesday and Saturday at $6 \mathrm{a} . \mathrm{m}$. or earlier to inspect whatever was brought in and to examine specimens for parasites. The story of his finds was told so vividly as to impart interest to the most trivial item. Leidy's quiet humor, which crops out more than once even in his exceedingly brief articles and which is commented on by his contemporaries, is beautifully illustrated by the few lines which Minot quotes from Leidy's story of his field trips.

“'Going fishing?' How often the question has been asked by acquaintances, as they have met me, with rod and basket, on an excursion after materials for microscopic study. 'Yes!' has been the invariable answer, for it saved much detention and explanation; and now, behold! I offer them the results of that fishing. No fish for the stomach, but, as the old French microscopist Joblet observed, 'some of the most remarkable fishes that have ever been seen': and food-fishes for the intellect." 
The "fishes" that he sought were Rhizopods which formed the basis of the magnificent monograph well known to all workers in natural history.

In his love of facts and his desire to go more deeply into life after them, he was devoted to the microscope and used it with a sharpness of vision and keenness of critical interpretation that yielded splendid results in fields that in his day had not even been outlined, much less developed. In this connection consider his observations on regeneration in Planaria, on the foundation of the cell wall after division of the cell, or the intimate structure of the cell in Rhizopoda, on parasites of many sorts, on protozoa and protophyta in his Flora and Fauna, and consider that it was only 1849 when he published his discovery of the existence of bacteria in the intestine.

The number, variety and range of Leidy's discoveries gave him unusual opportunity for speculation which was, moreover, the order of the day. His views on such undertakings are succinctly expressed in the preface to a monograph on the extinct mammals of Dakota. Though the subject lent itself admirably to the exercise of scientific imagination, he held himself rigidly to a recital of the facts and stated frankly, "No attempt has been made at generalizations or theories which might attract the momentary attention or admiration of the scientific community." And yet with all that no critic would be justified in charging Leidy with lack of scientific insight or with limited powers for interpreting the discoveries he made. The apparently trivial item became significant in his eyes and in connection with many discoveries he pointed out this import in a definite way that sometimes waited years for confirmation and utilization. As conspicuous instances of this, his indication of the role of flies in spreading disease, the interpretation of the relation between the trichina in pork and human parasitism and the significance of the hookworm in the production of anemia, all furnish evidence, more fully presented elsewhere in this sketch, of the power to anticipate to a remarkable degree the development of scientific thought in entirely new and most significant directions.

Leidy was preeminently a student of structure and in its minute determination he shows himself a master. His thesis for the M.D. degree was on The Comparative Anatomy of the Eye of Vertebrated Animals. His fame as a paleontologist rests on the painstaking and thorough analysis of anatomical detail. It was this same characteristic which made his work on parasitology so valuable and so permanent even though his descriptions of the parasites were unfortunately meager and not accompanied by those unsurpassed drawings which make the North American Rhizopods at once a marvel and a sure support for the student. 
Leidy's critical powers manifested themselves in the ability to recognize a group of structural features in a newly-encountered organism as distinct from a previously known combination of structures and to assign them an independent rank. In his day it was the custom to lump forms, to include a wide range of animals in a single genus for instance. Today it seems to be the fashion to make new genera on the slightest provocation. Now every worker follows naturally the practices of his age and it is not difficult to travel either road; but it requires genius to conform to the period in such fashion as to depart from its habits successfully when a later and better informed generation comes to pass judgment on the work. And that is precisely what Leidy did in parasitology. When European workers were crowding animals forcibly into vaguely defined genera, he working alone but with a keen eye for structural detail, saw that certain of the types he found could not possibly be forced into the time honored and universally accepted genera of his foreign confrères, so he made for them new genera and when Europe did not accept his findings he refused to rush into controversy but waited for time to decide. This work he did not in one group but in a wide range of forms and among the new genera he recognized and established one may cite the following as representative of his work in various groups:

Endamoeba, Dinamoeba, Ouramoeba, Nyctotherus and Trichonympha among the Protozoa; Phagocata, Catesthia, Anortha and Rhynchoscolex among the Turbellaria; Clinostomum and Cotylaspis among the Trematoda; Emea in Nemertines; Nema and Pontonema among the Anguillulidae; Streptostoma, Thelastoma, Hystrignathus and Synplecta among parasitic nematodes; Pectinatella and Urnatella in the Bryozoa, etc.

A few of these have suffered shipwreck on the rocks and shoals of nomenclatorial rules, but all were fundamentally sound and bear testimony today to the clarity of his conceptions of comparative anatomy.

Many striking instances could be cited to show how marvellously exact was Leidy's eye in detecting minute details of structure that escaped even the trained vision of other investigators. At the same time he manifested almost equally great powers in interpreting these observations. He was the first to include the Gregarines among animals and to describe certain minute fibrillae in those cells which he interpreted as the first traces of muscular structures. The older Van Beneden vigorously denied the existence of any such structures and it remained for his son many years later to confirm Leidy's observation and to acknowledge gracefully the father's error. In 1848 Leidy published a study on the comparative structure of the liver in which he advanced views at variance with the then accepted beliefs. His views were vigorously combated but have since been confirmed by embryological researches and are now generally accepted. In 1846 he found an encysted worm in the hog. $\mathrm{He}$ "could perceive no distinction 
between it and specimens of Trichina spiralis which he had met with in several human subjects." A European helminthologist doubted the determination and reclassified it as Trichina affinis but twenty years later the world came back to Leidy's views. So it was elsewhere also. His sharp vision detected the eye in Balanus and his record led Darwin to look for it in other members of the order. In the monograph on Fresh Water Rhizopods Leidy refers to his observation in 1844 of the amoeboid movement of the white blood corpuscles later described (in 1846) by Wharton Jones. In a manner illustrating at once his loyalty and his modesty he often said that this discovery rightly belonged to American science.

But it would be wrong to leave the impression that his work was exclusively or even preeminently taxonomic and descriptive. While he sought patiently to determine the precise facts and to assemble them in systematic order, his mind was keenly alive to the importance of biological data. He rarely communicated to the Academy a description that he did not enrich by salient observations on habits and on relations to man and other animals. In his Flora and Fauna Within Living Animals he emphasized the radical changes in form and the other complexities associated with the life history of parasitic animals. Many of his early notes deal with stages in such life histories and his paper on Nematoidea Imperfecta relates in 1851 an early effort to determine experimentally the adult forms arising from such larval stages.

No one can scan even the titles of Leidy's publications without being struck by their unusually broad range as well as by the number of contributions he made to science. He was writing in the same year, and often in the same month, or even reporting at the same meeting of the academy, studies on fossil vertebrates, protozoa, insects, minerals, parasites, human anatomy, bacteria, cell structure, and transplanting cancer! A more careful analysis of these publications discloses the fact that they fall into rather distinct groups representing four main currents of interest and activity: microscopic anatomy, paleontology, protozoology and parasitology. Furthermore, these lines of interest were developed in large part successively rather than synchronously so that they characterize certain periods in his life, even though not exclusively limited to any single period.

PIONEER WORK IN PARASITOLOGY

During the first years of Leidy's work as a contributor to scientific literature he confined his attention practically exclusively to the study of the minute anatomy of lower invertebrates and the quality of his work is well exemplified by the comments of Binney on the plates and descriptive text which Leidy, then barely 21 , contributed at the author's request to the well known work on Terrestrial Mollusks. Not until 1847 did he publish on paleontology and it was 1850 before studies on 


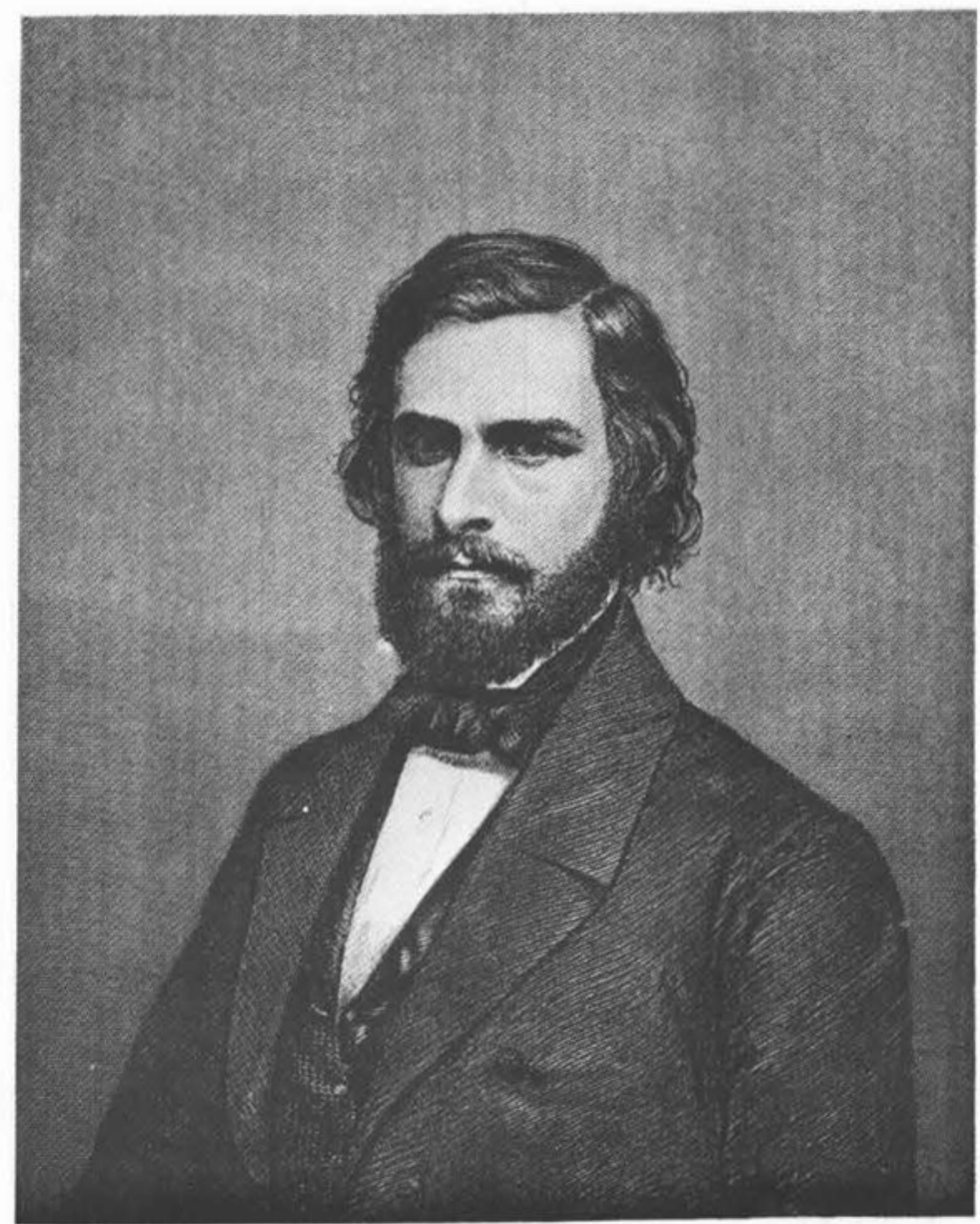

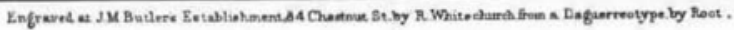

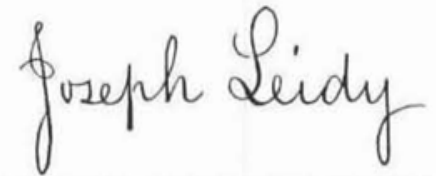

FROF.OF ANATOMY ON TWE UNOYELSUTY OF PPENN

PLATE II 
fossils assume a prominent place in his writings. During this period his papers show increasing attention devoted to the study of parasitic forms. In 1851 he completed his Flora and Fauna Within Living Animals, and his standing as a parasitologist was assured even if he had never written another line on the subject. But neither the interest in this field nor his work on it was terminated here.

The series of studies on parasitology made in this first period of scientific activity was brought together in a synopsis published in 1856 and in a series of additions and corrections that appeared two years later. This was distinctly a pioneer work as nothing of its kind had been attempted in this country previously, and it has remained almost the only publication of the kind available up to within recent years. The paper, which was entitled A Synopsis of Entozoa and Some of Their Ectocongeners, lists 172 species of parasitic protozoa, trematodes, cestodes and nematodes, including many new genera and species. In conformity with the usual custom of the time the descriptions are very brief and consequently often difficult to evaluate rightly. But they represent for that day unusual knowledge of detailed structure and keen judgment on the significance of structural features. The synopsis embraced thus a wide range of material and morever represented the work of a single investigator. In both aspects it was unique when compared with European publications of somewhat similar character and date.

But the newly undertaken studies on fossil vertebrates began to crowd out microscopical investigations and for nearly twenty years Leidy worked and published chiefly on paleontology. However, beginning about 1872 he devoted his attention assiduously again to microscopic studies, first on protozoa which held him closely until 1876, and after that once more to parasitology, the field in which he was primarily engaged during the last years of his life.

These changes in Leidy's activity were largely determined by external conditions and a letter to Baird, dated Nov. 20, 1850, when Leidy had just returned from Europe, shows vividly how he was tempted away from his early microscopical studies. After discussing his researches on parasitic forms he comments on Baird's offer of fossils from the Bad Lands and adds:

"You mention to me the reception of mammalian fossils from the mauvaisses terres by the Smithsonian Institution and obligingly offer them to me for 'working up.'

"I am delighted with such an opportunity. If you will send them to me I will describe them immediately and prepare a memoir for the Smithsonian. I can readily do it as they are comparatively easy. I can lay a specimen down and return to it at a leisure moment. Not so with microscopic investigation; it requires length of time without interruption which I cannot have during the winter; send them to me immediately ; good care will be taken of them." 
From 1856 to 1870 Leidy published very little on helminthology and only a few notes on miscroscopic anatomy of other forms. But then the tide turned once more. How conditions changed and the old work was resumed is beautifully told by Sir Archibald Geikie (1892):

"I cherish as one of the most memorable incidents of a visit which I paid to Philadelphia in the year 1879 my meeting with this distinguished naturalist and most lovable man. With what modesty he spoke of his own work, with what generous appreciation he referred to that of others, with what infinite patience and gentleness he would unfold and explain his views to any questioner who seemed to be interested in them! I well remember the pathos of his remarks as he told me how he had been led to abandon his researches in vertebrate paleontology and return to his first love-the rhizopods, on which he published that same year a magnificent monograph. 'Formerly,' he said, 'every fossil bone found in the States came to me, for nobody else cared to study such things. But now Professors —— with long purses, offer money for what used to come to me for nothing, and in that respect I cannot compete with them. So now, as I get nothing, I have gone back to my microscope and my rhizopods and make myself busy and happy with them.'"

ESTIMATES OF LEIDY'S WORK

Leidy's greatest work is recognized by all biographers as having been done in the field of vertebrate paleontology as shown in the number, breadth and accuracy of his studies, as well as in the splendid monographs of permanent value which he published in that field. And there is no reason to dissent from the view expressed by Geikie: "Dr. Leidy was universally acknowledged to be the Cuvier of American paleontology. And the praise lavished on him by his own fellow citizens was reechoed in no stinted measure in Europe." He was the first in the field and laid the foundations for the subsequent studies by a series of American investigators which have commanded the attention of scientific men both at home and abroad. The vast amount of paleontological material that was sent him between 1850 and 1860 drew his attention away from the studies he had so successfully inaugurated in other lines than this so that for nearly twenty years from 1856 to 1872 as already noted he published hardly more than a few brief notes in any other field. The splendid character of this work compels parasitologists to deplore the influences that drew him away from this earlier work and brings them to echo the remark of Kölliker to Leidy's nephew, "How I regret that your uncle ever saw a fossil bone."

To be sure, in this interval Leidy had published his text-book on human anatomy which is unexcelled in accuracy and clearness, and had also done splendid work as a surgeon in the Civil War, but after all these and certain other studies were but simple variations of the studies on gross anatomy which were incorporated in his paleontological contributions. About 1872 circumstances already noted carried him back to microscopic anatomy, his first love, and he spent several years in the study of the aquatic fauna which culminated in the appearance 
of his monograph on fresh water rhizopods in 1879. This work was important for its bearing on parasitology as he was led to study carefully the protozoan parasites, particularly in various groups of insects. But it does not appear just to assign to his studies on protozoa, as some biographers have done, a place among his contributions to knowledge which is second only to his work on vertebrate paleontology. Yet an equitable judgment concerning his work on parasitology can be passed only after a more careful analysis of the extent and precise character of his writings.

Leidy's publications were numerous: the published record lists about 600 and some few items at least were omitted. Many of these are exceedingly brief, ${ }^{2}$ being in fact only secretary's abstracts of oral discussions at the meetings of the Philadelphia Academy. Even these briefer notes are full of new information regarding structure, habits and relations and those bearing on helminthology and parasitology were in such constant demand that they were brought together and reprinted in 1904. They constitute the first and even yet the only extensive work in this field in America.

It is difficult to compare justly his work on parasitology with that in other lines. In number of titles it stands second to that in paleontology, and in major publications also. However, no single publication in parasitology achieved the perfection of his monograph on Fresh Water Rhizopods which stands today unexcelled in its field. On the other hand it is fair to say that the Flora and Fauna Within Living Animals was epoch-making in a sense that cannot be affirmed of any of his other writings outside the field of paleontology.

It has already been noted that Leidy's contributions to parasitology are pretty definitely limited to two periods in his career. Among the very first articles from his pen came two contributions to parasitology, one of which is the very important note on trichina to which more extended reference is made elsewhere. Between 1846 and 1858 he published some sixty notes and longer contributions in this field. Then for ten years one finds hardly a line on this subject. In 1870 contributions on parasitology began to appear again and are extended until in the last fifteen years of his life between 1876 and 1891 he contributed again about sixty papers on various topics in parasitology. He left an immense mass of unfinished material in the field, and as is well known, he had been planning for years the publication of an extended work on parasitology. Probably the most nearly completed of these unfinished

2. Osborn cites a fine comment by Calkins bearing on this point. "While these observations were made with keenness of perception, it must still be confessed that they were often expressed in quite too brief form for clear general understanding. In this he only followed the plan of his European contemporaries and while his ideas are distinct with the specimen itself in view, it is undoubtedly true that the originals must be worked over more fully." 
items was a set of manuscript notes and drawings on gregarines which was later incorporated into Crawley's monograph on the polycystid gregarines of the United States. Of the new genera which Leidy described among living animals, more than half were published between 1846 and 1858 , and nearly all of the rest after 1874 .

It is important to note also the range of work which he did in the field of parasitology. This is indicated in the first period of research activity in that field by the character of the synopsis referred to. Among the publications published in the second period between 1886 and 1891 are longer contributions on the tapeworms of birds, parasites of shad and herring, of termites, and on leeches. Almost the last publications from his pen were an extended article on entozoa printed in November, 1890, which dealt with a variety of parasites from different hosts, and a second printed in April, 1891, which was almost equally varied. The material which was left unfinished included studies on gregarines already referred to and other notes and drawings brought together by Nolan in five volumes of Leidyana, which constitute a mine of information for future investigation.

During this second period of productive work in parasitology Leidy completed one important contribution that has been overlooked by many because of the manner in which it was published. In 1882 for the American edition of Holmes, System of Surgery, he revised articles on Parasites and the Diseases They Produce, and on Venomous Insects and Reptiles, which appear with notes and observations in Volume III. In 1888 he wrote a treatise on Intestinal Worms for Pepper's System of Practical Medicine by Amorican Authors. This section, which covers thirty-five pages in the second volume, is the first comprehensive treatise on human parasites published on this continent.

\section{DISCOVERY OF TRICHINA IN PORK}

Among the very first of Leidy's contributions was a note recorded by the secretary of the Philadelphia Academy in October, 1846, as follows :

Dr. Leidy stated that he had lately detected the existence of an Entozoon in the superficial part of the extensor muscles of the thigh of a hog. The Entozoon is a minute, coiled worm, contained in a cyst. The cysts are numerous, white oval in shape, of a gritty nature, and between the 30th and 40th of an inch in length.

"The Entozoon he supposes to be the Trichina spiralis, heretofore considered as peculiar to the human species. He could perceive no distinction between it and the specimens of T. spiralis which he had met with in several human subjects in the dissecting rooms, where it had also been observed by others, since the attention of the scientific public had been directed to it by Mr. Hilton and Prof. Owen."

This has been regarded by some as Leidy's "most important practical contribution to helminthology" from the standpoint of public 
health. ${ }^{3}$ It is in fact a striking illustration of his keen scientific judgment and yet a closer analysis of the situation shows that the observation not only remained apparently unknown but was also without evident influence on European investigators, who were then engaged in an active controversy in their efforts to work out the life history of trichina and its relations to man. The case stands as follows: Leidy's record was copied in the Annals and Magazine of Natural History (1847) and incorporated by Diesing in his Systema Helminthum (1851) but the latter listed Leidy's find as a new species under the name Trichina affinis, grouping it with larval forms from a dozen other hosts, mostly birds. Several European writers cite the case under this new name, and no one under Leidy's original designation. Indeed Leidy was himself sufficiently impressed by the authority of Diesing that, without comment, in his Synopsis of the Entozoa (1856) he listed his form under Diesing's name and cited his own record as a synonym. But the forms which Diesing associated with Leidy's find are really Microfilariae and so unlike Trichina that if Leidy had known them at first hand he would have recognized the lack of relationship instantly. As the result of this misinterpretation and of scanty information regarding the discovery, Leuckart, Zenker, Virchow and others failed to mention it at all, or like Küchenmeister, utilized it to support the false * hypothesis that the encysted form in the pig was only the larval stage of the adult Trichocephalus in man. ${ }^{5}$ In consequence, Leidy's observation failed to contribute to the elucidation of the problem, as it might well have done. In 1859 Leidy exhibited to the Philadelphia Academy specimens of a Trichina found in the muscles of a human subject and stated that he often met with the parasite. In the following year he reported Leuckart's experiments showing Trichina was not the immature stage of a Trichocephalus or Stronglus, as had previously been generally believed. In 1866, the records of the Academy contain this interesting note:

3. I am unable to verify the statement of Garrison that in 1848 Leidy was "already well known through his contributions to natural sciences, particularly those on the Trichina." The statement is undoubtedly correct but the basis not well chosen as this particular item is almost unmentioned in European contemporaneous scientific literature and its deep significance nowhere recognized.

4. Küchenmeister (1855) says "glaube ich ... dass die kaum beträchtlich grösser zu nennende Trichina affinis Diesing's, die Leidy in Philadelphia in den Extensoren des Schenkels eines Schweines fand, mit unserer Trichina spiralis identisch gewesen sein dürfte.

5. The only mention Leukart makes of Leidy's work in his monograph and in his Menschliche Parasiten falls in connection with the historical survey, where he explains the view long held that Trichina was the larval form of Trichocephalus and shows how Leidy's discovery was naturally enough utilized to support this view. 
"In answer to a question from one of the members whether he had noticed Trichina in pork, Dr. L. observed that he had been the first to discover this parasite in the hog; the discovery having been made twenty years ago, as may be seen by referring to the Proceedings of this Academy for October, 1846. page 107-8. This notice had attracted the attention of the German helminthologist as proved by reference to Diessing's Systema Helminthum, vol. ii, pages 114, and Leuckart, Untersuchungen über Trichina spiralis, pages 6, 18.

"The circumstances under which the Trichina had been first detected in pork, was on an occasion when Dr. L. had dined on part of the infested meat. While eating a slice of pork, he noticed some minute specks, which recalled to mind the Trichina spots seen in the muscles of a human subject only a few days previously. Preserving the remainder of thè slice, on examination of it microscopically he found it full of Trichına spiralis, but the parasites were all dead from the heat of cooking. In conclusion, Dr. L observed that all meats were liable to be infested with parasites, but that there was no danger from infection if the meats were thoroughly cooked, for he had satisfied himself by experiment that entozoa are destroyed when submitted to the temperature of boiling water."

Even as late as 1876 Leuckart made a serious error in stating "das von Leidy (1847) beobachtete Vorkommen eines als Trichina affinis beschriebenen Wurmes aus dem Muskelfleische des Schweines," whereas Leidy only adopted that erroneous designation in 1856 under the influence of the great Diesing, at that time the accepted authority in parasitology. It would look as if even at this late date Leuckart was not clear regarding the exact facts in the case since he writes in the very next paragraph to that cited above, "Braucht man doch nur annehmen, dass die Trichina affinis mit der Trichina spiralis identisch sei was nach den Mittheilungen Leidy's trotz der abweichenden Benennung keineswegs unwarscheinlich war." (Italics not in original.)

In 1880 Nolan stated in a sketch of Leidy that "Leuckart afterwards acknowledged he was indebted to this communication for his success in tracing the development of Trichina in the hog and man." This comment must have been known to the European investigators and remains uncontradicted so far as I can find. Yet, I cannot locate any such acknowledgement in Leuckart's writings. When Leidy's nephew was in Berlin in 1896 Virchow told him personally that he had had a lengthy correspondence with Leidy in 1849 and 1850 just after he began his studies in pathology. This correspondence on Leidy's discovery of Trichina in pork, as Virchow stated in the conversation, suggested to him (Virchow) and Leuckart the scheme of experimentation on the life cycle of the parasite. Yet so far as I can find Virchow nowhere mentions Leidy in this writings.

Looking backward one can see how the life history of Trichina might have been interpreted many years in advance of its actual solution if the correct observations of Leidy had been accepted. But in fact, even the German investigators who knew of his work gave it no adequate consideration and many years elapsed before they came back by another route to the conception that the hog and man acted both equally as hosts for the parasites. 
This episode illustrates both the critical insight of the man and also his clear appreciation of the proper method for handling the danger, for as Leidy correctly stated in 1866, thorough cooking eliminates danger from infection by parasites. Even yet the world has not come to unanimous acceptance of this simple and universally successful method for preventing trichinosis, which he advocated. The case also illustrates Leidy's dislike of controversy for when his friends urged him to assert his part in the work and the importance of his discovery, he only replied that the discovery was merely one episode in his life and "the important thing is that the discovery or fact should be made known. It is of little consequence who made it." To him also controversy meant a "disturbance of that peace of mind" which was most distasteful and also interfered sadly with his researches.

SOME IMPORTANT OBSERVATIONS ON PARASITES

By virtue of the fact that Leidy was a pioneer in this field of work in America and that he was relied upon everywhere to furnish an explanation for the problems which were encountered, he was in receipt of material of the most varied type from all parts of the country and even from the Orient; thus, Dr. J. G. Kerr, one of the earliest missionaries in China, distinguished for his medical work, sent to Leidy in 1873 specimens of the intestinal fluke common there. It is not strange that at that date he confused the specimen with the liver fluke which is common here in cattle and sheep. This error he found and rectified later. Leidy not only recorded one of the very first occurrences of many important parasites, especially those of man; he also recognized promptly the significance of their presence, and put on record for the guidance of others interpretations which are of marked significance in view of the limited knowledge concerning these forms current at that time. This was clearly shown in this original record of presence of trichina in the hog already discussed. In 1878 he discussed the distribution and frequence of the two human tapeworms, and was the first to show that contrary to the ordinarily accepted belief, Taenia saginata was much more common than the pork tapeworm, Taenia solium. He notes in connection with this case the fact of evident significance that the carrier of the specimen "had been in the habit of eating raw buffalo meat." It is evidently possible that this was a specimen of some now exceedingly rare species rather than that to which he referred it, for as has been pointed out by several recent students, the native herbivores of North America may have sheltered species of tapeworm closely allied to but not identical to those reported from the old world. Isolated specimens which lend color to such a view have been described under different names (Taenia confusa and Taenia abietina); but be that as it may, Leidy recognized instantly the bear- 
ing of the patient's diet on the problem of his infestation with the tapeworm. In 1879 Leidy reported specimens of the fish tapeworm, Dibothriocephalus latus, which had come from a native of Sweden that had been in the country only a few months. They were the first of the species which Leidy had seen in a host living in this country. In 1884 Leidy called attention to specimens of Taenia flavopunctata, now better known as Hymenolepis diminuta. These came from a child only three years of age and the species had been observed but once previously. Leidy pointed out definitely the probability that the worm is more common than might be inferred from cases on record. He further suggested that it has probably escaped notice from its diminutive size and from lack of knowledge of tapeworms in general. The more recent studies of Ransom on this species have abundantly justified Leidy's prediction made thirty years before. In 1886, writing on parasitic worms, Leidy recorded the discovery in the cat of a form which he listed under the name Ancylostoma duodenale. It is true that in all probability he had not the species named but a closely related one that is often parasitic in the cat. This does not in the least affect his general conclusion that the discovery indicates the probability that it also infests man and is one of the previously unrecognized causes of pernicious anemia. It was many years later that the well known and important work of Ashford, Stiles and others, disclosed the full significance for the human species on this continent of the hookworm and associated anemia.

Leidy's faculty to draw correct inferences from his observations and to apply them for the guidance of men is illustrated by many simple suggestions that were appended to his discussions of unusual and important parasites. They are handled so naturally that the careless observer might regard them as casual observations or after thoughts, but this can hardly suffice to explain their frequence and value. As early as 1853 he wrote, "Cooking food is of advantage in destroying the germs of parasites, and hence man, notwithstanding his liability to the latter, is less infested than most other mammalia." In 1878 when reporting on parasites received from physicians who expressed apprehension about them and thought they had traced several cases of illness to the use of food infested with worms, Leidy in discussing the particular situation observed that as already well known to naturalists most animals are infested with parasites which are transmitted in feeding. "The remedy against transmission was heat. He who uses only well cooked foods need have no apprehension from such foods." Or again as he said in March, 1866, when discussing trichina, "All meats were liable to be infested with parasites, but there was no danger from infection if the meats were thoroughly cooked, for he had satisfied himself by experiment that entozoa are destroyed when brought to the temperature of boiling water." 


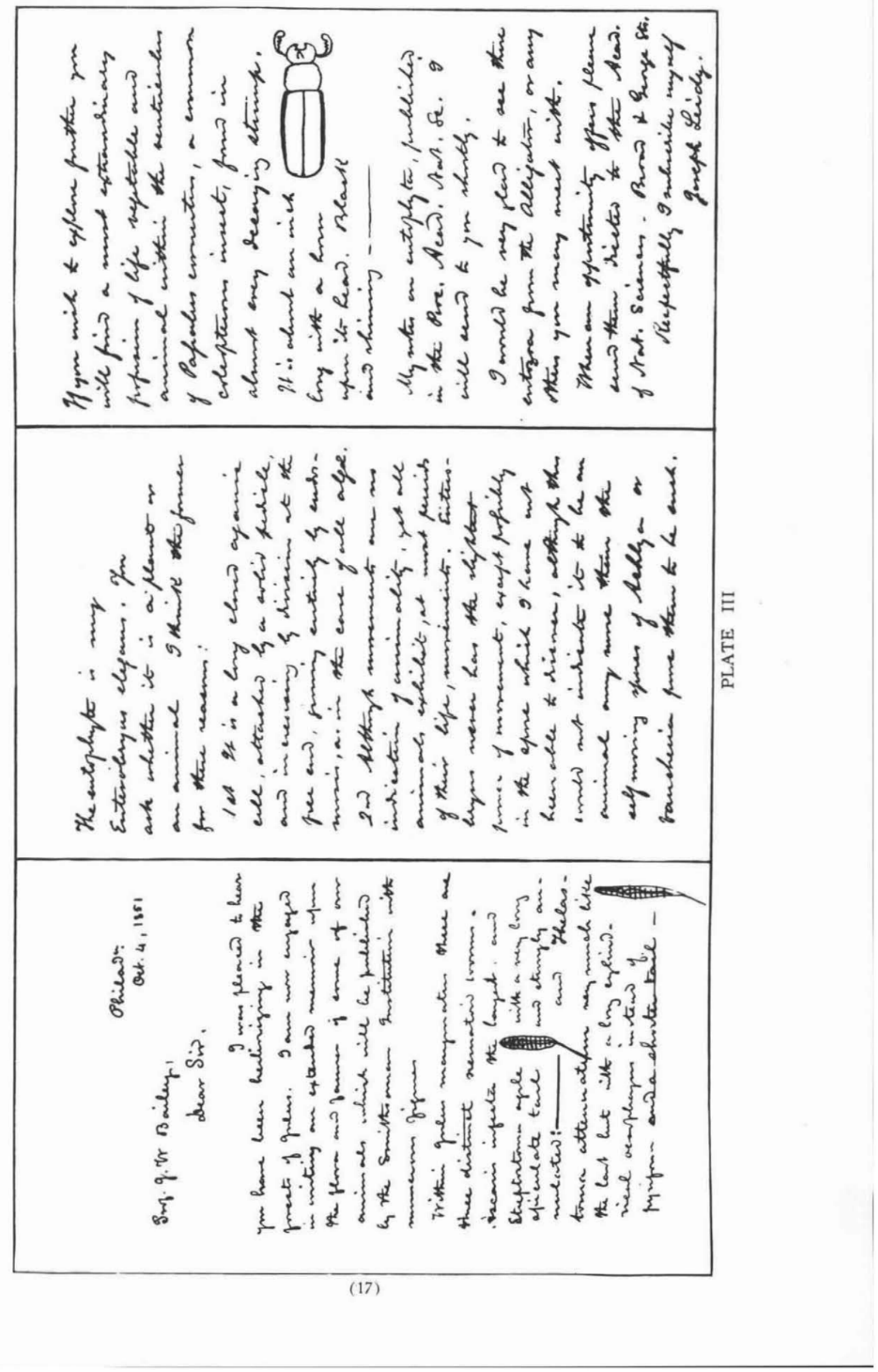


Another simple illustration will suffice to elucidate this characteristic. In November, 1871, he discussed flies as a means of communicating contagious diseases and stated that on the basis of his observations during the Civil War in a large military hospital where gangrene existed he believed that flies should be excluded from contact with the wounded. Recently he had found some flies that when caught and examined were swarming with spores of a fungus on which they had just fed. In view of the apparent ease with which he found a reasonable solution to most of the problems which presented themselves it is interesting to note his comment on the occurrence of a reputed tapeworm in a cucumber, concerning which he writes, "It cannot be admitted that the worm belonged to the cucumber, nor is it clear how it reached this position."

LEIDY'S MASTER WORK IN PARASITOLOGY

Leidy's most influential publication on parasitology was, in my opinion, A Flora and Fauna Within Living Animals, accepted for publication in December, 1851, and printed in the Smithsonian Contributions to Knowledge in 1853 . The article is not large as it covers only 67 pages. It is, however, beautifully illustrated by ten plates and handles in a powerful manner not only the scientific facts observed, but the general discussion of their bearing on important general problems. In an intensive study of the intestinal canal of a myriapod and a beetle, Leidy demonstrated the occurrence of a typical flora and fauna which was both rich and varied. ${ }^{6}$ His anatomical descriptions and illustrations are unsurpassed in their clarity and exactitude and are unequalled in the literature of the time. He did not content himself with a description of structure but worked out the development of the parasites and their relation to the organs of the host in which they occurred. He contrasted further the true plant parasites with the pseudo-entophytes which he encountered. It is in his general discussion that one finds after all the most striking evidences of the unusual character of this contribution. To judge the situation rightly, one must keep in mind the fact that this paper was written before the epoch making investigations of Pasteur, Tyndall and others had established on a firm foundation present day conceptions with reference to the origin of living organisms. The doctrine of equivocal or spontaneous generation was

6. Even earlier than this in his Researches in Helminthology (1849) he wrote "I have found numerous free or floating entophyta in the contents usually in the posterior part of the alimentary canal in mammals, aves, reptilia, pisces, mollusca, etc." This is, I think, the earliest demonstration of the bacterial flora of the intestine, and it was certainly thoroughly followed out and firmly established by the range of hosts he cited from almost the entire animal kingdom. I am informed that these views are more fully elaborated in his yet unpublished personal correspondence with Baird. 
widely held and vigorously supported by men of high rank in scientific circles. To be sure it had lost the crude form in which it had been stated by students of medieval times and earlier days, but it was accepted with reference to the simplest microscopic organisms all the more generally because the very arguments that had disproved the possibility of its occurrence among complicated organisms lent color to the likelihood of its being found among those of the simplest type. The entozoa had always furnished the strongest support for the theory, and the complexity of their development, which had in large part eluded the efforts of investigators, gave additional weight to the view that these organisms arose de novo where they were discovered.

In the beginning of this paper Leidy says, "The very great majority of modern observations indicate that entozoa and entophyta are produced from germs derived from parents and have a cyclical development." To the readers of those days such phrases did not carry the demonstrative character that they present to modern students. It was a distinct challenge to the advocates of spontaneous generation. After reviewing the difficulties due to the fact that entozoa pass various stages of existence under totally different circumstances and undergo pronounced modifications in form such that successive stages cannot be recognized as such without further evidence, Leidy denies the necessity of spontaneous generation and challenges the supporters of the doctrine to present one single direct observation to substantiate it. His review of the general conditions of the earth and the phenomena of life in its relation to environmental factors is in general terms almost the same as that given by Huxley fully twenty years later. Many of the statements and the entire line of explanation anticipated in a definite way the views which in greater fullness found their expression eight years later in Darwin's Origin of Species. He refers to his own repetition of the experiments made by Schulze to test the possibility of spontaneous generation, and while acknowledging that negative results may not be conclusive, he states, "Be this as it may, the most prolonged and the most carefully conducted experiments have not led to the proof of a single instance of equivocal or spontaneous generation, even among the simplest of all living beings: but on the contrary that all lead further and further from or entirely disproved it." He then considers the factors concerned in the development of parasitic life and the relative abundance of parasites among animals of different habitats. In his discussion of the influence of parasites on the production of diseases, occurs a statement that has sometimes been misconstrued. He wrote, "That malaria and epidemic fevers have their origin in cryptogamic vegetables or spores requires yet a single proof. He was referring to "an ingenious little work by my distinguished friend, Dr. J. K. Mitchell on the cryptogamous origin of malarious and epidemic fevers." This 
statement has been interpreted as indicating that Leidy "discussed the cause of malaria and wrongly construed that it was not of parasitic origin." The examination of the context shows that in the first half of the same sentence he acknowledges the agency of entophyta in the production of certain diseases and in the following sentence refers to the fact that "vegetables or spores conveyed through the air and introduced into the body through respiration could be detected," as indeed he himself had done in this very work while tracing the origin and development of the enteric flora which he described.

Leidy closed this general section of his paper with a list of described species of parasitic plants and animals to which man is subject. The thoroughness with which he has here demonstrated the origin and development of so varied a flora and fauna within the animals he studied was in a positive and convincing fashion an argument against the doctrine of spontaneous generation quite as powerful to many minds as the later experiments of the European investigators. In any event the work was read and quoted generally among European investigators and elicited everywhere outspoken praise. ${ }^{7}$

It is important to note that Leidy's critique of the theory of spontaneous generation was preeminently that of a biologist and included arguments that even Pasteur could not have formulated. In a footnote, for example, he writes :

"The experiments of Crosse and Weeks appear to me exceedingly absurd; for, in the first case, how were the carbon and nitrogen of the animal body to be derived by the play of a voltaic current upon a solution of silicate or potassa? If they previously existed in the water, was it not quite as probable that the ova of Acari were there also? Again, when the solution of ferrocyanide of potassium was made the womb of life by the electrical current, why could not the embryology of the new being be observed? An Acarus is a highly complex animal, presenting a well-developed tegumentary, muscular, and nervous system, and a digestive, respiratory, and generative apparatus. The gap between the inorganic world and the Acarus is greater than that between the latter and man."

It was this paper inter alia that almost prevented his election to the chair of Anatomy at the University of Pennsylvania in 1853 as he was charged with attempting to overthrow the Mosaic record of creation through his geological teachings and his attack upon spontaneous generation!

\section{CONCLUSION}

A detailed study of his writings justifies the statement that no one has yet adequately presented or fully elucidated Leidy's contrįbutions to helminthology and his writings will furnish rich leads to many future

7. Professor Henry, Secretary of the Smithsonian Institution, sums up his report on this publication with these words: "the whole forming the most remarkable paper on physiology which has ever been produced by one of our countrymen." 
workers in this field. How monumental the task of preparing a record of the full life work of this extraordinary man who in the same breath as it were, in a single letter records discoveries of far reaching import on bacteria, amoebae, worms, and fossil elephants.

Many biographical sketches, especially those written by his associates in the Philadelphia Academy, show that in the later years of his life Leidy had in mind the publication of an extensive work on parasitology ${ }^{8}$ and the articles he published in those years dealt preeminently with that topic. All must regret that this project remained unrealized for he left a vast amount of unpublished data in this field and of this only a small part, that on Gregarinida, has been in shape for later publication. Fortunately his nephew brought together all of his writings on parasitology and they were reprinted in 1904 by the Smithsonian Institution under the title of Researches in Helminthology and Parasitology. ${ }^{9}$ One must regret that these notes had not been rewritten by the master mind and his later studies incorporated. But even though the earlier items have an archaic cast and the work suffers from its natural discontinuity, yet it is a mine of information on American parasitology which even yet is far from worked out and will always be indispensible to investigators in this field. Despite all the defects incident to such a compilation it is a monument to the industry and ability of the author and foreshadows the monograph he had in mind but was not able to complete.

HenRy B. Ward.

\section{ILLUSTRATIONS}

Plate I

Frontispiecc.-Portrait of Leidy taken in 1883 when he was 60 years of age.

Plate II

Facing page 8 . Copy of steel engraving representing Leidy at 28 ; taken in 1851, the year in which he completed his Flora and Fauna within Living Animals.

Plate III

Facsimile of letter in Leidy's handwriting ( $2 / 3$ natural size); on page 17.

Professor J. W. Bailey to whom this letter was written was a distinguished member of the faculty at West Point Military Academy from 1838 to 1857. His scientific reputation was achieved principally by his researches in microscopy in which field he was a pioneer in the United States.

8. See Sketch of Joseph Leidy by E. J. Nolan (1889).

9. Smithsonian Misc. Collect., Vol. 46; 281 pp. No. 1477, 1904. 


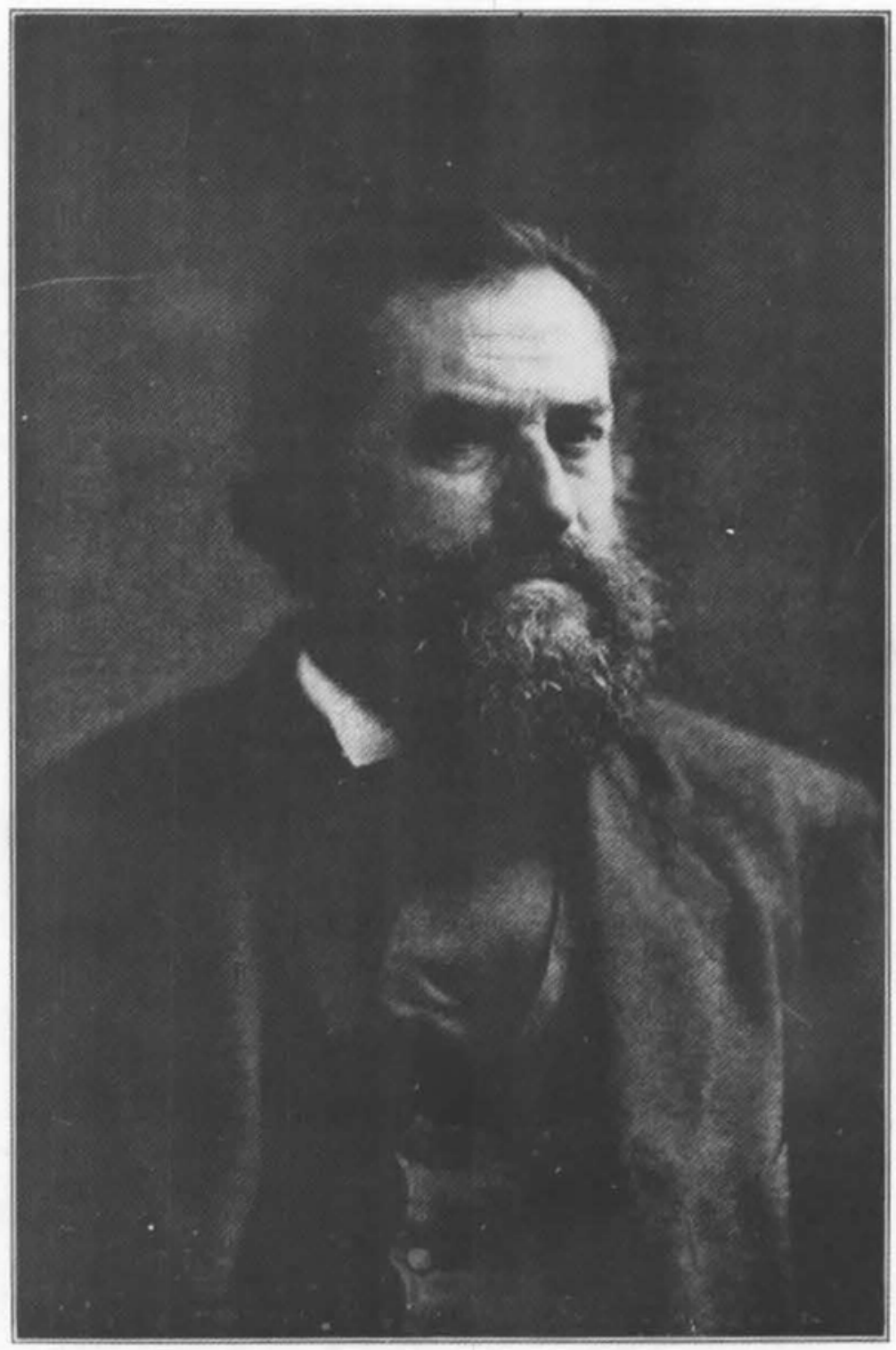

DR. JOSEPH LEIDY. 1823-1891. 